\title{
An octavalent vaccine provides pregnant gilts protection against a highly virulent porcine parvovirus strain
}

\author{
Erwin van den Born ${ }^{*}$ (D, Paul P. M. van den Elzen, Emma van Kilsdonk, Mathieu J. H. Hoeijmakers \\ and Ruud P. A. M. Segers
}

\begin{abstract}
Background: Porcilis ${ }^{\oplus}$ Ery+Parvo+Lepto is an octavalent inactivated ready-to-use vaccine that contains Erysipelothrix rhusiopathiae (Ery), porcine parvovirus (PPV), and six serogroups of Leptospira (Lepto). The efficacy of Porcilis ${ }^{\oplus}$ Ery + Parvo+Lepto against reproductive problems associated with porcine parvovirus (PPV) infection was evaluated in pregnant gilts. For this, a group of ninegilts was vaccinated twice (at 5 and 6 months old) with Porcilis ${ }^{\oplus}$ Ery + Parvo+Lepto (Group 1), while a group of eight gilts was included as unvaccinated controls (Group 2). All pigs were artificially inseminated 4 weeks after the second vaccination. They were challenged during early gestation with PPV27 a, a virulent cluster D strain, and euthanized to collect their offspring by hysterectomy around day 90 in pregnancy. Antibody responses against PPV in gilts were measured, and the presence of PPV in progeny was also determined.
\end{abstract}

Results: No clinical signs were observed after vaccination. After PPV challenge, all foetuses from the vaccinated gilts were alive (132/132), while in the unvaccinated group only $41 \%$ were alive (46/112), $19.6 \%$ were dead and 39.4\% of the offspring (44/112) were mummified. PPV could be detected by qPCR in $14 \%$ of the progeny from vaccinated gilts at an average of $4.7 \log _{10} / \mathrm{ml}$, whereas this was significantly higher in the control group, where $90 \%$ of the progeny were PPV positive, with titres of $9.8 \log _{10} / \mathrm{ml}$ on average.

Conclusions: The present study demonstrates that vaccination of gilts with Porcilis ${ }^{\oplus}$ Ery + Parvo+Lepto was safe and induced an immune response sufficient to protect progeny against PPV by reducing transplacental infection.

Keywords: Porcine parvovirus, Vaccination, Pregnant gilts, Mummification

\section{Background}

Porcine parvovirus (PPV) is present in the majority of pig herds worldwide and is the most common and important cause of infectious infertility. It causes reproductive losses represented by stillbirth, mummification, embryonic death, infertility (SMEDI-syndrome) and delayed return to oestrus. Parvovirus infection in nonpregnant adult pigs rarely causes clinical signs, but during pregnancy the virus can cross the placental barrier to infect the rapidly dividing tissues of the embryos and foetuses. The outcome of the PPV infection of the foetus varies with the progression of gestation [1]. Foetuses infected early in pregnancy usually die, resulting in their

\footnotetext{
* Correspondence: erwin.van.den.born@merck.com

MSD Animal Health, P.O. Box 31, 5830 AA Boxmeer, The Netherlands
}

mummification or resorption, whereas foetuses infected at a later timepoint develop antibodies against PPV and may survive, but as a result of the infection may be weak at birth [2].

PPV is a member of the genus Parvovirus within the family Parvoviridae. It is a small, nonenveloped, single-stranded DNA virus. Although PPV replicates by using the host DNA replication machinery, it exhibits a relatively high mutation rate that is more similar to RNA viruses [3]. PPV variants are continuously evolving and this raises the question whether established vaccine strains that were isolated several decades ago are still providing protection [4]. Such a more divergent variant, PPV-27a, was isolated in Germany in 2001 and has now been phylogenetically

(C) The Author(s). 2020 Open Access This article is distributed under the terms of the Creative Commons Attribution 4.0 International License (http://creativecommons.org/licenses/by/4.0/), which permits unrestricted use, distribution, and 
categorized as a cluster D strain [5, 6]. A high rate of foetal mummification was observed after infection of pregnant gilts with strain PPV-27a [4].

Swine erysipelas (caused by Erysipelothrix rhusiopathiae) is a disease of greatest prevalence and economic importance [7]. Leptospirosis (caused by Leptospira interrogans sensu lato) is also a cause of reproductive failure in pigs worldwide [8]. Vaccines against erysipelas and parvovirus are routinely used in the pig industry whereas leptospirosis vaccines are used less commonly. For user convenience and to reduce the number of injections given to gilts and sows, a ready-to-use combination product was developed by adding six relevant swine Leptospira antigens (serogroups Canicola, Icterohaemorrhagiae, Australis (Bratislava), Grippotyphosa, Pomona and Tarassovi) to an existing vaccine, Porcilis ${ }^{\bullet}$ Ery + Parvo. This new octavalent inactivated vaccine, Porcilis ${ }^{\oplus}$ Ery + Parvo+Lepto, was found to be safe and efficacious against each of the infectious agents [9, 10]. Naïve animals require two vaccinations of this vaccine, 4 weeks apart. Immunity can be maintained by revaccinating pigs according to the schedule described in the product leaflet of Porcilis ${ }^{\circ}$ Ery + Parvo+Lepto.

The goal of this study was to evaluate the efficacy of Porcilis $^{\circ}$ Ery + Parvo+Lepto, containing the PPV-014 strain, against reproductive disorders associated with PPV infection of pregnant gilts that were challenged during early gestation with the contemporary and virulent PPV-27a strain.

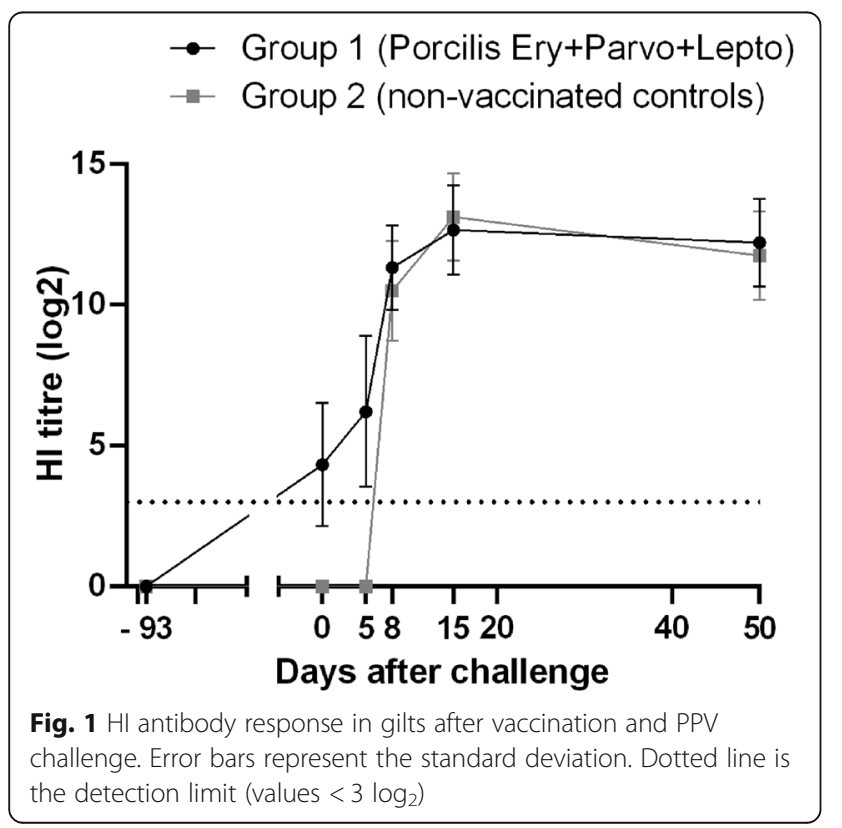

\section{Results}

Clinical signs and serological response after vaccination with Porcilis ${ }^{\oplus}$ Ery + Parvo+Lepto

No clinical signs were observed after vaccination of the gilts with Porcilis ${ }^{\bullet}$ Ery + Parvo+Lepto.

At the first vaccination, all gilts were negative for PPV antibodies. At the time of challenge, 93 days after the first vaccination, one-third of the gilts vaccinated with Porcilis ${ }^{\bullet}$ Ery + Parvo+Lepto had developed detectable HI antibodies, while none of the challenge control gilts in Group 2 showed a measurable $\mathrm{HI}$ antibody response (Fig. 1). After challenge, all gilts developed HI titres against PPV.

\section{Vaccination of gilts with Porcilis ${ }^{\oplus}$ Ery + Parvo+Lepto protected the progeny from PPV-induced death}

Vitality of the progeny is showed in Table 1. A total of 132 foetuses were collected from the pregnant gilts in Group 1 of which all were alive. The control gilts had a total of 112 foetuses of which 46 were alive, 22 dead and 44 mummified. The calculated percentages of vital foetuses per group clearly demonstrate that a reduction in foetal mortality can be achieved by vaccinating gilts with Porcilis Ery + Parvo+Lepto (Fig. 2).

\section{Vaccination of gilts with Porcilis ${ }^{\oplus}$ Ery + Parvo+Lepto reduced transplacental infection}

The infectivity data is summarized in Table 1 . It was established that $90 \%$ of the offspring of the control gilts were infected by PPV, as material taken from these foetuses was PCR, HA, and/or HI positive. In contrast, 14\% of the offspring of the Porcilis ${ }^{\circ}$ Ery + Parvo+Lepto vaccinated gilts were PPV positive by PCR, and no response was detectable by HA or HI assays.

When comparing the PPV DNA load in the foetuses of the group 1 and group 2 gilts, it was observed that vaccination with Porcilis ${ }^{\oplus}$ Ery + Parvo+Lepto reduced the average viral DNA content in PPV-positive foetal tissue homogenates significantly, from $9.8 \log _{10} / \mathrm{ml}$ to 4.7 $\log _{10} / \mathrm{ml}(P<0.0001)$.

\section{Discussion}

Vaccination ensures active immunity against PPV in gilts and sows and is the most effective tool to prevent PPVinduced losses in the breeding herd. This study demonstrates that the octavalent Porcilis ${ }^{\oplus}$ Ery + Parvo+Lepto vaccine is safe, as no clinical signs were observed after vaccination in any of the gilts. The study also demonstrates that the vaccine protects against reproductive losses associated with PPV infection of pregnant gilts. The gilts were challenged with PPV-27a, a more contemporary cluster D strain, while the PPV strain in the vaccine belongs to cluster A [1]. The VP1 protein of PPV-27a shows 
Table 1 Vitality and presence of PPV in foetuses per sow.

\begin{tabular}{|c|c|c|c|c|c|c|c|c|c|c|}
\hline \multirow[t]{2}{*}{ Group } & \multirow[t]{2}{*}{ Sow No. } & \multicolumn{4}{|c|}{ Vitality in progeny } & \multicolumn{4}{|c|}{ PPV infection in progeny } & \multirow[b]{2}{*}{$\%$ Protected } \\
\hline & & Total & Alive & Dead & Mummified & $\begin{array}{l}\text { PPV } \\
\text { Ag } \\
\text { Pos } \\
\text { (HA } \\
\text { titre) }\end{array}$ & $\begin{array}{l}\text { PPV } \\
\text { Ab } \\
\text { Pos } \\
\text { (HI } \\
\text { titre) }\end{array}$ & $\begin{array}{l}\text { PPV } \\
\text { DNA } \\
\text { Pos } \\
\text { (qPCR) }\end{array}$ & $\begin{array}{l}\text { PPV-Pos } \\
\text { HI,HA, and/ } \\
\text { or qPCR }\end{array}$ & \\
\hline \multirow[t]{2}{*}{1} & 226 & 11 & 11 & 0 & 0 & 0 & 0 & 0 & 0 & \\
\hline & 227 & 15 & 15 & 0 & 0 & 0 & 0 & 2 & 2 & \\
\hline \multirow{9}{*}{$\begin{array}{l}\text { Porcilis Ery + } \\
\text { Parvo + Lepto }\end{array}$} & 229 & 8 & 8 & 0 & 0 & 0 & 0 & 0 & 0 & \\
\hline & 230 & 21 & 21 & 0 & 0 & 0 & 0 & 4 & 4 & \\
\hline & 231 & 14 & 14 & 0 & 0 & 0 & 0 & 2 & 2 & \\
\hline & 232 & 17 & 17 & 0 & 0 & 0 & 0 & 2 & 2 & \\
\hline & 233 & 13 & 13 & 0 & 0 & 0 & 0 & 3 & 3 & \\
\hline & 235 & 16 & 16 & 0 & 0 & 0 & 0 & 4 & 4 & \\
\hline & 236 & 17 & 17 & 0 & 0 & 0 & 0 & 2 & 2 & \\
\hline & Total & 132 & 132 & 0 & 0 & 0 & 0 & 19 & 19 & \\
\hline & Percentage & $100 \%$ & $100 \%$ & $0 \%$ & $0 \%$ & $0 \%$ & $0 \%$ & $14 \%$ & $14 \%$ & $85.6 \%$ \\
\hline \multirow[t]{2}{*}{2} & 2 & 16 & 3 & 2 & 11 & 11 & 4 & 15 & 16 & \\
\hline & 3 & 12 & 4 & 4 & 4 & 4 & 4 & 11 & 12 & \\
\hline Control & 4 & 16 & 1 & 9 & 6 & 6 & 3 & 16 & 16 & \\
\hline \multirow[t]{7}{*}{ Non vac. } & 5 & 18 & 12 & 3 & 3 & 3 & 5 & 18 & 18 & \\
\hline & 6 & 10 & 9 & 1 & 0 & 0 & 0 & 4 & 4 & \\
\hline & 9 & 17 & 8 & 3 & 6 & 6 & 0 & 12 & 12 & \\
\hline & 10 & 13 & 0 & 0 & 13 & 13 & 0 & 13 & 13 & \\
\hline & 11 & 10 & 9 & 0 & 1 & 1 & 0 & 8 & 8 & \\
\hline & Total & 112 & 46 & 22 & 44 & 44 & 16 & 97 & 99 & \\
\hline & Percentage & $100 \%$ & $41 \%$ & $20 \%$ & $39 \%$ & $40 \%$ & $15 \%$ & $90 \%$ & $90 \%$ & $10 \%$ \\
\hline
\end{tabular}

$A g$ antigen; $A b$ antibody; Pos positive

a 97.8\% sequence identity compared to PPV-014 (results not shown). This observation is in accordance with previously reported studies, which demonstrate that the German field isolates such as PPV-27a differ genetically from various vaccine strains $[3,5]$. Even though our vaccine strain is not closely related to the challenge strain used in the study, Porcilis ${ }^{\oplus}$ Ery + Parvo+Lepto conferred good protection after experimental infection. Animals were fully protected from clinical disease, however PPV DNA was detected in foetuses from vaccinated gilts, albeit at a much lower level than in the unvaccinated controls. This observation is in accordance with previous studies that described viral shedding in vaccinated, clinically protected animals following heterologous or homologous PPV challenge $[11,12]$.

Previous reports have described detection of PPVspecific antibodies as early as day 6 post-infection and the peak antibody titres on days 14-21 after infection [1], which is in agreement with our findings (Fig. 1).
Foerster et al. demonstrated that vaccination with inactivated PPV-27a prevented foetal death after homologous virus challenge with PPV-27a. However, a substantial increase in antibody titres was observed after infection, indicating virus replication in the immunised animals [12]. In our study, both groups responded serologically after challenge, reaching similar peak levels of $\mathrm{HI}$ antibodies.

PPV neutralization assays would have been useful to confirm that the detected HI antibodies were neutralizing antibodies. Virus isolation from mummified piglets would also have been useful to verify that PPV detected by PCR was infectious or not. Unfortunately, these techniques could not be performed for this study.

Despite the virulence described for strain PPV-27a after experimental infection of pregnant gilts [4], the mortality rate among the foetuses of the vaccinated and unvaccinated gilts differed significantly: in Porcilis ${ }^{\oplus}$ Ery + Parvo+Lepto vaccinated gilts (group 1) $100 \%$ of the foetuses were alive and unaffected, while in unvaccinated gilts (group 2) more than half (58.9\%; 66 out of 112) of 


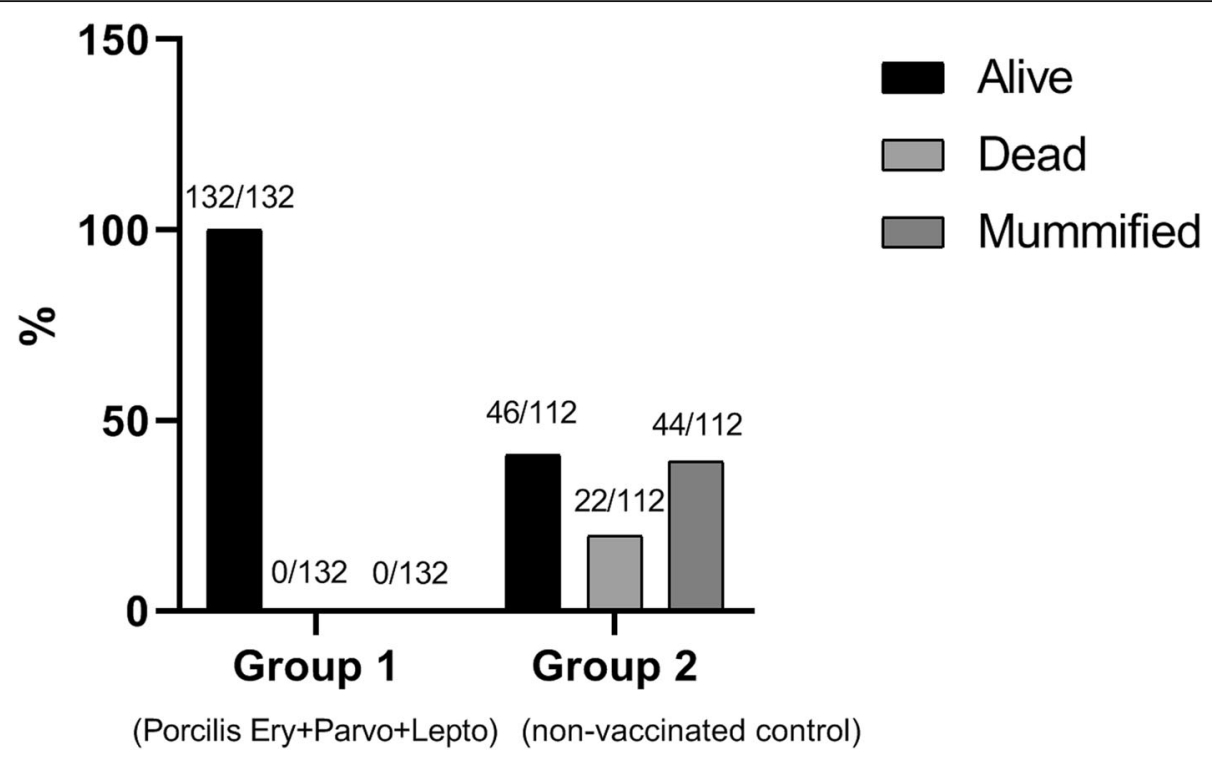

Fig. 2 Vitality of the progeny at around day 90 in pregnancy

the foetuses were dead or mummified (Fig. 2). These results demonstrate the effectiveness of the two-dose vaccination strategy for Porcilis ${ }^{\oplus}$ Ery + Parvo+Lepto.

Regarding PPV infection of the progeny, more foetuses in the control group were infected by the PPV-27a strain than the foetuses in the Porcilis ${ }^{\oplus}$ Ery + Parvo+Lepto vaccinated group ( $90 \%$ versus $14 \%$ respectively; Table 1 ) and also more severely (i.e. higher level of viral copies in group 2). This result agrees with previous studies, which also used the virulent PPV-27a strain and found high foetus mortality $[4,11,12]$, although it has to be noted that positive PCR results may represent the transplacental transfer of non-infectious virus or PPV DNA [4].

Porcilis $^{\oplus}$ Parvo and Porcilis ${ }^{\oplus}$ Ery+Parvo, two other PPV-containing vaccines, carry the same cluster A parvovirus strain as Porcilis ${ }^{\oplus}$ Ery + Parvo+Lepto. It is therefore anticipated that these vaccines will provide protection against more recent and virulent cluster $D$ strains like PPV-27a, similar to Porcilis ${ }^{\oplus}$ Ery + Parvo+Lepto. An alternative study in which pregnant gilts were vaccinated once with Porcilis $^{\oplus}$ Ery + Parvo before insemination, and subsequently challenged with PPV27a has confirmed this (unpublished). This is a relevant observation, because in recent years there is a predominance of the European strains in related clusters $\mathrm{C}$ and $\mathrm{D}[3]$.

\section{Conclusions}

In summary, vaccination of gilts with Porcilis ${ }^{\circledR}$ Ery + Parvo+Lepto was safe and effectively reduced foetal mortality caused by infection of pregnant pigs by the virulent PPV-27a strain.

\section{Methods}

Experimental design of the animal trial

Two groups of randomly selected PPV-negative healthy gilts (Fokbedrijf VOF Jacobs, The Netherlands) were included in the study (Table 2). After an acclimatization period, animals in Group $1(n=9)$ were vaccinated intramuscularly in the neck with Porcilis ${ }^{\oplus}$ Ery + Parvo+Lepto (batch IP141910) when they were approximately 5 months old and were revaccinated 4 weeks later. The gilts in Group $2(n=8)$ were not vaccinated and served as challenge controls. In the 3 weeks following the last vaccination, the oestrus of all gilts was synchronized by Regumate treatment following the manufacturer's instructions (MSD Animal Health). Maprelin was administered 2 days after the last Regumate treatment and 3 days before the first insemination to enhance the success of the insemination. Four weeks after the last vaccination, all pigs were artificially inseminated with PPV-free sperm on two to three consecutive days. Around day 40 in pregnancy, gilts were challenged with the virulent strain PPV-27a. Around day 90 in pregnancy, gilts were exsanguinated after having been anaesthetised by electrocution and the offspring were obtained by hysterectomy. If the foetus was mummified, the entire foetus was collected. Serum was collected from the live foetuses and body fluid from dead foetuses. Serum, body fluid samples and homogenates of the mummified foetuses were tested for the presence of PPV and/or PPV-specific antibodies. Blood samples of the gilts were collected before the first vaccination, at challenge and 5, 8 and 15 days after challenge and at the end of the experiment. Blood samples were tested for the presence of antibodies 
against PPV. Treatment, housing and husbandry conditions conformed to the guidelines of the European Union for animal welfare and the study was performed according to Good Experimental Practices.

\section{Vaccine}

The Porcilis Ery + Parvo+Lepto vaccine (MSD Animal Health) contains the Diluvac Forte ${ }^{\odot}$ adjuvant, inactivated Erysipelothrix rhusiopathiae, inactivated porcine parvovirus, and six Leptospira interrogans serogroups, i.e. Canicola, Icterohaemorrhagiae, Australis (Bratislava), Grippotyphosa, Pomona and Tarassovi.

\section{PPV challenge material}

PPV 27a strain, kindly provided by Prof. Truyen [4], was cultured on SK6 cells and stored at $-70^{\circ} \mathrm{C}$ until use. Shortly before use, the challenge material was diluted using $0.01 \mathrm{M}$ PBS to contain a concentration of $6.0 \log _{10}$ $\mathrm{TCID}_{50} / \mathrm{ml}$. The challenge consisted of $2 \mathrm{ml}$ of the virus given intranasally and $2 \mathrm{ml}$ intramuscularly. Thus, a calculated total dose of $6.6 \log _{10} \mathrm{TCID}_{50}$ per animal.

\section{Sample processing}

Blood was collected in vacutainers without anticoagulant and allowed to coagulate. Serum was prepared from the clotted blood samples by centrifugation (3000x g, $10 \mathrm{~min}$ ), aliquoted and stored at $-20^{\circ} \mathrm{C}$ until use.

Homogenates of the entrails of the foetus $(20 \% \mathrm{w} / \mathrm{v})$ were individually prepared in $200 \mathrm{mM}$ glycine buffer $\mathrm{pH}$ 9.5 using an IKA tube drive station and stored at $-20^{\circ} \mathrm{C}$ until use.

\section{Haemagglutination inhibition ( $\mathrm{HI}$ ) assay for the detection of antibodies to PPV}

Sera from gilts and body fluid or sera from foetuses were tested for the presence of antibodies that inhibit the haemagglutination of guinea pig red blood cells by PPV in a HI assay. Two-fold dilution series of $50 \mu \mathrm{L}$ of the test samples were prepared in micro-titre plates and mixed with an equal volume of a solution containing 48 HA units of PPV. A positive and negative control was included. After incubation for $45 \mathrm{~min}$ at room temperature, red blood cells were added to a final concentration of $0.33 \%$. After incubation overnight at $2-$ $8^{\circ} \mathrm{C}$, plates were examined for red blood cell agglutination. The titre of antibodies inhibiting agglutination of the red blood cells by PPV was expressed as $\log _{2}$. The detection limit was $4 \log _{2}$. Samples below that value were considered negative. To be able to calculate the average of PPV antibody titres, an HI titre of $<4 \log _{2}$ was defined as a titre of $3 \log _{2}$. An HI titre of $>15 \log _{2}$ was defined as a titre of $16 \log _{2}$. For representation purposes, an average titre of $3 \log _{2}$ was set at 0 .

\section{Haemagglutination (HA) assay for the detection of PPV}

The amount of PPV in mummified piglet homogenates was quantified using its ability to agglutinate guinea pig red blood cells (HA assay). The HA test was performed on supernatant obtained after centrifugation of the homogenate at $1000 \mathrm{xg}$ for $10 \mathrm{~min}$ at $4{ }^{\circ} \mathrm{C}$. Two-fold dilution series of $50 \mu \mathrm{L}$ of test sample in $50 \mu \mathrm{L}$ of HA buffer $(0.1 \%(\mathrm{v} / \mathrm{v})$ BSA in PBS) were mixed in V-shaped micro titre plates. An equal volume of $50 \mu \mathrm{L}$ of guinea pig red blood cells was added. A positive and negative control was included. After incubation for $2 \mathrm{~h}$ at $2-8{ }^{\circ} \mathrm{C}$ plates were examined for agglutination of the red blood cells. The antigen content was expressed as $\log _{2}$ HA unit per $50 \mu \mathrm{L}$. The detection limit was $1 \log _{2}$. Samples showing $<1 \log _{2}$ were considered negative.

\section{PPV-specific quantitative polymerase chain reaction (qPCR)}

Sera or body fluid from progeny or mummy-homogenates were analyzed by qPCR for the presence of PPV DNA. Amplified DNA-fragments were detected by using SYBR green that only fluoresces when bound to DNA. The amount of PPV DNA in a sample was determined by including in each test a 10-fold serial dilution of a reference standard (plasmid pPPV-02 containing a $4.5 \mathrm{~kb}$ PstI-DraI fragment of PPV strain NADL-8). A melt curve was used to analyze the specificity of the signal. Samples giving a $C_{q}$ value below 40 and a specific melt curve were considered positive. Samples not fulfilling both criteria were considered negative. The PPV content of positive samples was expressed as $\log _{10}$ copies per $\mathrm{ml}$.

\section{Statistical analysis}

Viral load data in foetuses were analysed with a mixed model ANOVA with group as fixed effect and

Table 2 Overview of groups and their treatment.

\begin{tabular}{|c|c|c|c|c|c|c|c|}
\hline \multirow[b]{2}{*}{ Group } & \multirow[b]{2}{*}{$\begin{array}{l}\text { No. of } \\
\text { gilts }\end{array}$} & \multicolumn{2}{|c|}{ Vaccination at 5 months of age } & \multicolumn{2}{|c|}{ Vaccination at 6 months of age } & \multicolumn{2}{|c|}{ Challenge infection at 40 days in pregnancy } \\
\hline & & Vaccine & $\begin{array}{l}\text { Dose/ } \\
\text { Route }\end{array}$ & Vaccine & $\begin{array}{l}\text { Dose/ } \\
\text { Route }\end{array}$ & challenge strain & $\begin{array}{l}\text { Dose/ } \\
\text { Route }\end{array}$ \\
\hline 1 & 9 & EPL & $\begin{array}{l}2 \mathrm{ml} \\
\mathrm{IM}\end{array}$ & EPL & $\begin{array}{l}2 \mathrm{ml} \\
\mathrm{IM}\end{array}$ & $27 a$ & $\begin{array}{l}2 \times 1 \mathrm{ml} \mathrm{IN} \\
2 \mathrm{ml} \mathrm{IM}\end{array}$ \\
\hline 2 & 8 & - & - & & & $27 a$ & $\begin{array}{l}2 \times 1 \mathrm{ml} \mathrm{IN} \\
2 \mathrm{ml} \mathrm{IM}\end{array}$ \\
\hline
\end{tabular}


accounting for the correlation within a litter by including gilt, representing the litter, as random effect. The Dunnett's multiple comparison method was used in comparing each vaccine group to the control. In the calculations qPCR results $<$ LOQ where replaced by LOQ$0.3\left(\log _{10}\right)$, reflecting one duplication in the amplification. This is considered as a conservative approach in estimating the difference in viral load between the vaccine and control group since the majority in the vaccine group was $<\mathrm{LOQ}$ and in the control almost all were $>$ LOQ.

Tests were 2-sided at a significance level of $5 \%$. SAS version 9.3 (SAS Institute Inc., Cary, NC, USA) was used for the statistical analysis.

\section{Abbreviations}

ANOVA: Analysis of variance; BSA: Bovine serum albumin;

DNA: Deoxyribonucleic acid; HA: Haemagglutination; HI: Haemagglutination Inhibition; LOQ: Limit of quantification; PBS: Phosphate-buffered saline; PPV: Porcine parvovirus; SK6 cells: Swine Kidney 6 cells; $\mathrm{TCID}_{50}$ : Tissue culture infective dose (50\%)

\section{Acknowledgements}

The authors thank Jeroen Verbruggen for his technical assistance. Prof. Dr. Uwe Truyen (University of Leipzig) kindly provided the PPV 27a strain. We are very grateful to Cristina Lorca-Oró for providing professional writing services and help with generating figures.

\section{Authors' contributions}

EvdB designed the trial; EvdB, PvdE, and EvK performed the experiment; EvdB and EvK wrote the manuscript; $\mathrm{MH}$ performed the statistical analysis; RS provided scientific input and reviewed the manuscript. All authors read and approved the final manuscript

\section{Funding}

No external funding was obtained for this study.

\section{Availability of data and materials}

The datasets generated and/or analysed during the current study are not publicly available due to the size of the dataset ( 244 piglets and 17 gilts), but are available from the corresponding author on reasonable request.

\section{Ethics approval and consent to participate}

The study was approved after ethical evaluation by the Animal Welfare Body of MSD Animal Health. The committee's reference number for this study is EPD 14.053 .

\section{Consent for publication}

Not applicable.

\section{Competing interests}

All authors are employed by MSD Animal Health.

Received: 5 July 2019 Accepted: 3 February 2020

Published online: 12 February 2020

\section{References}

1. Mészáros I, Olasz F, Cságola A, Tijssen P, Zádori Z. Biology of porcine parvovirus (ungulate parvovirus). Viruses. 2017;9:393.

2. Berns K, Parrish CR. Parvoviridae. In: Knipe DM, Howley PM, editors. Fields virology. 6th ed. Philadelphia: Lippincott Williams \& Wilkins; 2013. p. 1768-91.

3. Streck AF, Bonatto SL, Homeier T, Souza CK, Gonçalves KR, Gava D, Canal $\mathrm{CW}$, Truyen U. High rate of viral evolution in the capsid protein of porcine parvovirus. J Gen Virol. 2011;92:2628-36.

4. Zeeuw EJL, Leinecker N, Herwig V, Selbitz HJ, Truyen U. Study of the virulence and cross-neutralization capability of recent porcine parvovirus field isolates and vaccine viruses in experimentally infected pregnant gilts. J Gen Virol. 2007;88:420-7.

5. Zimmermann P, Ritzmann M, Selbitz HJ, Heinritzi K, Truyen U. VP1 sequences of German porcine parvovirus isolates define two genetic lineages. J Gen Virol. 2006;87:295-301.

6. Streck AF, Canal CW, Truyen U. Molecular epidemiology and evolution of porcine parvoviruses. Infect Genet Evol. 2015;36:300-6.

7. Wood RL. Erysipelas. In: Leman AD, Straw BE, Mengeling WL, D'Allaire S, Taylor DJ, editors. Diseases of Swine. 7th ed. lowa State: Univ. Press, Ames, IA; 1992. p. 475-86.

8. Ellis WA. In: straw BE, Zimmerman JJ, D'Allaire S, Taylor DJ, editors Leptospirosis, chapter 41, diseases of swine. 9th ed. Ames, IA: Blackwell Publishing; 2006.

9. Jacobs AAC, Harks F, Hoeijmakers M, Collell M, Segers RPAM. Safety and efficacy of a new octavalent combined erysipelas, Parvo and Leptospira vaccine in gilts against Leptospira interrogans serovars Pomona associated disease and foetal death. Vaccine. 2015;33:3963-9.

10. Jacobs AAC, Harks F, Hoeijmakers M, Segers RPAM. A novel octavalent combined erysipelas, Parvo and Leptospira vaccine provides (cross) protection against infection following challenge of pigs with 9 different Leptospira interrogans serovars. Porcine Health Manag. 2015;1:16.

11. Jóźwik A, Manteufel J, Selbitz HJ, Truyen U. Vaccination against porcine parvovirus protects against disease, but does not prevent infection and virus shedding after challenge infection with a heterologous virus strain. J Gen Virol. 2009;90:2437-41.

12. Foerster T, Streck AF, Speck S, Selbitz HJ, Lindner T, Truyen U. An inactivated whole-virus porcine parvovirus vaccine protects pigs against disease but does not prevent virus shedding even after homologous virus challenge. J Gen Virol. 2016;97:1408-13.

\section{Publisher's Note}

Springer Nature remains neutral with regard to jurisdictional claims in published maps and institutional affiliations.
Ready to submit your research? Choose BMC and benefit from:

- fast, convenient online submission

- thorough peer review by experienced researchers in your field

- rapid publication on acceptance

- support for research data, including large and complex data types

- gold Open Access which fosters wider collaboration and increased citations

- maximum visibility for your research: over $100 \mathrm{M}$ website views per year

At BMC, research is always in progress.

Learn more biomedcentral.com/submissions 